\title{
Derangements of liver tissue bioenergetics in Concanavalin A-induced hepatitis
}

\author{
Mariam Al-Shamsi ${ }^{1}$, Allen Shahin ${ }^{1}$, Eric PK Mensah-Brown ${ }^{2^{*}}$ and Abdul-Kader Souid ${ }^{3^{*}}$
}

\begin{abstract}
Background: A novel in vitro system was employed to investigate liver tissue respiration (mitochondrial $\mathrm{O}_{2}$ consumption) in mice treated with concanavalin A (Con A). This study aimed to investigate hepatocyte bioenergetics in this well-studied hepatitis model.

Methods: $\mathrm{C} 57 \mathrm{BI} / 6$ and $\mathrm{C} 57 \mathrm{BI} / 6 \mathrm{IFN}-\gamma^{-/-}$mice were injected intravenously with $12 \mathrm{mg}$ ConA/kg. Liver specimens were collected at various timepoints after injection and analyzed for cellular respiration and caspase activation. Serum was analyzed for interferon-gamma (IFN- $\gamma$ ) and aminotransferases. Fluorescence activated cell sorting analysis was used to determine the phenotype of infiltrating cells, and light and electron microscopy were used to monitor morphological changes. Phosphorescence analyzer that measured dissolved $\mathrm{O}_{2}$ as function of time was used to evaluate respiration.
\end{abstract}

Results: In sealed vials, $\mathrm{O}_{2}$ concentrations in solutions containing liver specimen and glucose declined linearly with time, confirming zero-order kinetics of hepatocyte respiration. $\mathrm{O}_{2}$ consumption was inhibited by cyanide, confirming the oxidation occurred in the respiratory chain. Enhanced liver respiration (by $\approx 68 \%, p<0.02$ ) was noted $3 \mathrm{hr}$ after ConA treatment, and occurred in conjunction with limited cellular infiltrations around the blood vessels. Diminished respiration (by $\approx 30 \%, p=0.005$ ) was noted $12 \mathrm{hr}$ after ConA treatment, and occurred in conjunction with deranged mitochondria, areas of necrosis, and prominent infiltrations with immune cells, most significantly, $\mathrm{CD}^{+} \mathrm{NKT}^{+}$cells. Increases in intracellular caspase activity and serum IFN- $\gamma$ and aminotransferase levels were noted $3 \mathrm{hr}$ after ConA treatment and progressed with time. The above-noted changes were less pronounced in C57BI/6 IFN- $\gamma^{-/-}$mice treated with ConA.

Conclusions: Based on these results, liver tissue bioenergetics is increased $3 \mathrm{hr}$ after ConA exposure. This effect is driven by the pathogenesis of the disease, in which IFN- $\gamma$ and other cytokines contribute to. Subsequent declines in liver bioenergetics appear to be a result of necrosis and active caspases targeting the mitochondria within hepatocytes.

Keywords: Concanavalin A (ConA), Hepatitis, Caspase, AST, ALT, IFN- $\gamma$

\section{Background}

The term "cellular bioenergetics" describes the biochemical processes involved in energy metabolism (energy conversion or transformation), and the term "cellular respiration" (mitochondrial oxygen consumption) describes the delivery of metabolites and oxygen $\left(\mathrm{O}_{2}\right)$ to the mitochondria, the

\footnotetext{
*Correspondence: ericb@uaeu.ac.ae; asouid@uaeu.ac.ae

${ }^{2}$ Department of Anatomy, College of Medicine and Health Sciences, United Arab Emirates University, Al Ain, Abu Dhabi, United Arab Emirates (UAE) ${ }^{3}$ Department of Pediatrics, College of Medicine and Health Sciences, United Arab Emirates University, Al Ain, Abu Dhabi, United Arab Emirates (UAE) Full list of author information is available at the end of the article
}

oxidation of reduced metabolic fuels with the passage of electrons to $\mathrm{O}_{2}$, and the synthesis of ATP. Impaired cellular bioenergetics or respiration thus entails an interference with any of these metabolic processes.

Concanavalin A (ConA) is a plant lectin from seeds of Canavalia ensiformis [Jack bean] that serves as a polyclonal T-cell mitogen and is also used to induce hepatitis in mice. Murine ConA-induced hepatitis is a well-studied model that mimics human liver viral infections $[1,2]$. The liver injury is typically noted within $3 \mathrm{hr}$ of intravenous injection of ConA $(12 \mathrm{mg} / \mathrm{kg})$ and progresses with time [2]. Activation and recruitment of natural killer $\mathrm{T}(\mathrm{NK} \mathrm{T})$

\section{Biomed Central}


and other cells of the innate immune system are early events that, in turn, lead to secretion of inflammatory cytokines, such as interferon- $\gamma$ (IFN- $\gamma$ ), tumor necrosis factor (TNF)- $\alpha$, interleukin (IL)-12, and IL-18 [3]. This biochemical burst of inflammatory mediators targets multiple organs, including the liver. Its outcome is a hepatotoxicity that is characterized by mononuclear cellular infiltration and foci of necrosis [4].

The potential role of NK T cells in the pathogenesis of ConA-induced hepatitis is confirmed by the observation that mice lacking NK T cells and those treated with antiIFN- $\gamma$ antibody (to counter this essential inflammatory mediator released by NK $\mathrm{T}$ cells) are both resistant to ConA-induced hepatitis. In addition, targeting NK $\mathrm{T}$ cells with glucocerebroside, a naturally occurring glycolipid that inhibits NK T cell proliferation, ameliorates ConA-induced hepatitis [5]. These findings suggest the pathological outcome of the liver in ConA-treated animals relies on initial activation of innate immune components, such as NK T cells, followed by subsequent activation and recruitment of effector immune cells, including macrophages and T-cells. We confirm here that the pathology of concanavalin A-induced hepatitis is dependent on activated immune cells especially NK T cells and the secretion of cytokines, including IFN- $\gamma$, and mice in which the cytokine is genetically deleted develop a milder form of the disease.

ConA-induced hepatitis is associated with caspase activation [6]. Caspase-3, a cysteine aspartate-directed protease and a family member of the IL-1 1 -converting enzyme (ICE), is the key executer of apoptosis. This enzyme is involved in proteolysis of several proteins, including poly (ADP ribose) polymerase; it cleaves at the C-terminal to $\mathrm{Asp}^{216}$ in the DEVD (asp-glu-val-asp) sequence. This 4-amino-acid motif has been utilized for the highly-specific caspase-3 substrate, Ac-DEVD-AMC ( $N$-acetyl-DEVD-7amino-4-methyl-coumarin). Caspase-3 cleaves the tetrapeptide between $\mathrm{D}$ and $\mathrm{AMC}$, releasing the fluorogenic moiety 7-amino-4-methylcoumarin (AMC) that can be separated on HPLC and detected by fluorescence [7].

The status of liver tissue mitochondrial $\mathrm{O}_{2}$ consumption in ConA-induced hepatitis is unknown. In this study, compound alterations in liver tissue respiration were noted early in the course of the induced hepatitis. The inflammatory cytokines, including IFN- $\gamma$ appear to contribute to these deleterious changes in hepatocyte energy metabolism.

The effect of inflammatory bursts on hepatocyte bioenergetics is unknown, especially in ConA-induced hepatitis. In theory, inflammatory cytokines are expected to enhance cellular energy metabolism; however, this phenomenon has not yet been investigated and answers are needed. This present study attempts to address some of these queries. Measuring liver tissue respiration, using the principle that $\mathrm{O}_{2}$ quenches the phosphorescence of palladium (Pd) II-meso-tetra-(4-sulfonatophenyl)-tetrabenzoporphyrin, has been recently reported [8-10]. This analytical tool is used here to monitor liver tissue $\mathrm{O}_{2}$ consumption in ConA-induced hepatitis in mice.

\section{Methods \\ Reagents}

The Pd(II) complex of meso-tetra-(4-sulfonatophenyl)tetrabenzoporphyrin ( $\mathrm{Pd}$ phosphor) was obtained from Porphyrin Products (Logan, UT). Dactinomycin (actinomycin $\mathrm{D}, \mathrm{MW} \approx 1255$ ) was purchased from Merck (Whitehouse Station, NJ). A lyophilized powder of caspase inhibitor I (zVAD-fmk, MW $\approx 467.5$ ) was purchased from Calbiochem (La Jolla, CA). Ac-DEVD-AMC (MW $\approx 729.6$ ) and caspase- 3 (molecular mass $\approx 30.5 \mathrm{kDa}$, heterodimer active human recombinant) were purchased from Axxora LLC (San Diego, CA). Glucose [anhydrous], ConA (from Canavalia ensifomis, Jack bean, Type IV-S), bovine serum albumin (free of endotoxin and fatty acids), and remaining reagents were bought from Sigma-Aldrich (St. Louis, MO).

Dactinomycin solution was made fresh in $\mathrm{dH}_{2} \mathrm{O}$; its concentration was determined by absorbance at $440 \mathrm{~nm}$, using an extinction coefficient of $24,450 \mathrm{M}^{-1} \cdot \mathrm{cm}^{-1}$ [7]. The zVAD-fmk solution (2.14 $\mathrm{mM})$ was made by dissolving $1.0 \mathrm{mg}$ of $\mathrm{zVAD}-\mathrm{fmk}$ in $1.0 \mathrm{ml}$ of dimethyl sulfoxide and stored at $-20^{\circ} \mathrm{C}$. The Ac-DEVD-AMC caspase substrate was dissolved in dimethyl sulfoxide at a concentration of $6.85 \mathrm{mM}$ and stored at $-20^{\circ} \mathrm{C}$ in small aliquots. Phosphate-buffered saline (PBS) with glucose (137 mM NaCl, $2.7 \mathrm{mM} \mathrm{KCl}, 4.3 \mathrm{mM} \mathrm{Na} \mathrm{HPO}_{4}, 1.4$ $\mathrm{mM} \mathrm{KH}_{2} \mathrm{PO}_{4}$, and $5 \mathrm{mM}$ glucose; $\mathrm{pH} 7.4$ ) was made fresh. ConA (5 mg) was suspended in $3 \mathrm{ml}$ sterile PBS $(\mathrm{f} / \mathrm{c}=\sim 1.67 \mathrm{mg} / \mathrm{ml})$; aliquots were stored at $-20^{\circ} \mathrm{C}$. Pd phosphor solution $(2.5 \mathrm{mg} / \mathrm{ml}=2 \mathrm{mM})$ was prepared in $\mathrm{dH}_{2} \mathrm{O}$ and stored in aliquots at $-20^{\circ} \mathrm{C}$. $\mathrm{NaCN}$ solution $(1.0 \mathrm{M})$ was prepared in $\mathrm{dH}_{2} \mathrm{O}$; the $\mathrm{pH}$ was adjusted to $\sim 7.0$ with $12 \mathrm{~N} \mathrm{HCl}$ and stored at $-20^{\circ} \mathrm{C}$.

\section{Mice}

Male C57Bl/6 and C57Bl/6 IFN- $\gamma^{-1-}$ mice (8-12-wk-old; weight $\approx 18-22 \mathrm{~g}$ ) used in this study were maintained at an animal facility that was in compliance with $\mathrm{NIH}$ guidelines (http://grants.nih.gov/grants/olaw/references/ phspol.htm). The mice were purchased from The Jackson Laboratory (Bar Harbor, ME). All mice were housed in rooms maintained at $22^{\circ} \mathrm{C}$ with $\sim 60 \%$ relative humidity and a 12-hr light/dark cycle. All mice had ad libitum access to standard rodent chow and filtered water. All protocols here received approval from the Animal Ethics Committee-United Arab Emirates University - College of Medicine and Health Sciences.

For these studies, experimental mice were given a single intravenous injection $(12 \mathrm{mg} / \mathrm{kg}$ body weight in a total 
volume of $300 \mu \mathrm{l}$ ) of ConA in PBS or PBS alone in the tail vein. At $0-12 \mathrm{hr}$ after the treatment, mice were euthanized by intra-peritoneal injection of $100 \mu \mathrm{l} / 10 \mathrm{~g}(\mathrm{BW})$ of urethane (using $20 \%$ solution $[\mathrm{w} / \mathrm{v}]$ in $0.9 \% \mathrm{NaCl}$ ) and blood was collected from the sino-orbital orifice; serum was subsequently prepared by standard protocols. At necropsy, liver specimens were collected for analyses.

\section{Liver tissue}

Liver specimens (18-30 mg/mouse) were excised using a sharp pair of scissors (Moria Vannas Wolg Spring, cat. \# ST15024-10, Cambridge, UK). Following protocols previously outlined [8,9], the specimens were immediately immersed in ice-cold oxygenated Krebs-Henseleit buffer $\left(115 \mathrm{mM} \mathrm{NaCl}, 25 \mathrm{mM} \mathrm{NaHCO}, 1.23 \mathrm{mM} \mathrm{NaH}_{2} \mathrm{PO}_{4}, 1.2\right.$ $\mathrm{mM} \mathrm{Na}_{2} \mathrm{SO}_{4}, 5.9 \mathrm{mM} \mathrm{KCl}, 1.25 \mathrm{mM} \mathrm{CaCl}_{2}, 1.18 \mathrm{mM}$ $\mathrm{MgCl}_{2}$, and $6 \mathrm{mM}$ glucose [pH 7.2]), weighed and then placed in $1.0 \mathrm{ml}$ Krebs buffer containing $0.5 \%$ fat-free bovine albumin and $3 \mu \mathrm{M}$ Pd phosphor for $\mathrm{O}_{2}$ measurements. Unless otherwise noted, the time period between specimen collection and start of $\mathrm{O}_{2}$ measurement was $<5$ min. Where stated, specimens were incubated in vitro at $37^{\circ} \mathrm{C}$ in Krebs-Henseleit solution gassed with 95\% $\mathrm{O}_{2}: 5 \%$ $\mathrm{CO}_{2}$ prior to $\mathrm{O}_{2}$ measurements.

Specimens were also fixed in $4 \%$ phosphate-buffered paraformaldehyde and embedded in paraffin wax blocks. Sections of the fixed liver pieces (of 5-7 $\mu \mathrm{m}$ thickness) were stained with haematoxylin and examined under a light microscope. Sections of the harvested liver were also placed in Karnovsky's solution and processed for electron microscopy [8].

\section{Oxygen measurements}

A phosphorescence oxygen analyzer was used to monitor $\mathrm{O}_{2}$ consumption by liver specimens $[8,9]$. $\mathrm{O}_{2}$ detection was performed with the aid of $\mathrm{Pd}$ phosphor that had an absorption maximum at $625 \mathrm{~nm}$ and a phosphorescence maximum at $800 \mathrm{~nm}$. Samples were exposed to light flashes (600 per min) from a pulsed light-emitting diode array with peak output at $625 \mathrm{~nm}$ (OTL630A-5-10-66-E, Opto Technology, Inc., Wheeling, IL). Emitted phosphorescent light was detected by a Hamamatsu photomultiplier tube (928) after first passing it through a wide-band interference filter centered at $800 \mathrm{~nm}$. The amplified phosphorescence decay was digitized at $1.0 \mathrm{MHz}$ by a $20-\mathrm{MHz} \mathrm{A} / \mathrm{D}$ converter (Computer Boards, Inc., Mansfield, MA).

A program was developed using Microsoft Visual Basic 6, Microsoft Access Database 2007, and Universal Library components (Universal Library for Measurements Computing Devices; http://www.mccdaq.com/daq-software/ universal-library.aspx). It allowed direct reading from the PCI-DAS 4020/12 I/O Board (PCI-DAS 4020/12 I/O Board; http://www.mccdaq.com/ pci-data-acquisition/PCIDAS4020-12.aspx). The pulse detection was accomplished by searching for 10 phosphorescence intensities $>1.0$ volt (by default). Peak detection was accomplished by searching for the highest 10 datapoints of a pulse and choosing the datapoint closest to the pulse decay curve [10].

The phosphorescence decay rate $(1 / \tau)$ was characterized by a single exponential; $\mathrm{I}=\mathrm{Ae}^{-t / \mathrm{\tau}}$, where $\mathrm{I}=\mathrm{Pd}$ phosphor phosphorescence intensity. The values of $1 / \tau$ were linear with dissolved $\mathrm{O}_{2}: 1 / \tau=1 / \tau^{\circ}+k_{q}\left[\mathrm{O}_{2}\right]$, where $1 / \tau=$ the phosphorescence decay rate in the presence of $\mathrm{O}_{2}, 1 / \tau^{\mathrm{o}}=$ the phosphorescence decay rate in the absence of $\mathrm{O}_{2}$, and $k_{\mathrm{q}}=$ the second-order $\mathrm{O}_{2}$ quenching rate constant in $\sec ^{-1} \cdot \mu \mathrm{M}^{-1}[11]$.

Liver tissue respiration was measured at $37^{\circ} \mathrm{C}$ in $1 \mathrm{ml}$ sealed vials. Mixing was carried out with the aid of parylene-coated stirring bars. In vials sealed from air, $\left[\mathrm{O}_{2}\right]$ decreased linearly with time, indicating the kinetics of mitochondrial $\mathrm{O}_{2}$ consumption was zero-order. The rate of respiration ( $k$, in $\left.\mu \mathrm{M} \mathrm{O}_{2} / \mathrm{min}\right)$ was thus the negative of the slope $\mathrm{d}\left[\mathrm{O}_{2}\right] / \mathrm{d} t$. Sodium cyanide $(\mathrm{NaCN})$ inhibited respiration, confirming that $\mathrm{O}_{2}$ was being consumed in the mitochondrial respiratory chain (Additional file 1: Figure S1).

\section{Calibration with $\beta$-glucose plus glucose oxidase}

The calibration reaction contained PBS with $3 \mathrm{mM}$ Pd phosphor, $0.5 \%$ fat-free albumin, $50 \mathrm{mg} / \mathrm{ml}$ glucose oxidase and various concentrations of $\beta$-glucose. The values of $1 / \mathrm{t}$ were linear with [ $\beta$-glucose]; the value of $k_{\mathrm{q}}$ was the negative of the slope $\left(k_{\mathrm{q}}=101.1 \mathrm{sec}^{-1} \cdot \mu \mathrm{M}^{-1}\right)$. The value of $1 / \tau$ for air-saturated solution (without glucose) was $28,330 \mathrm{sec}^{-1}$ (coefficient of variation, $\mathrm{C}_{\mathrm{v}}=12 \%$ ) and for $\mathrm{O}_{2}$-depleted solution (with $500 \mathrm{mM} \beta$-glucose, $1 / \tau_{\mathrm{o}}$ ) $2,875 \sec ^{-1}\left(C_{v}=1 \%\right)$. The high values of $C_{v}$ for the air-saturated solutions were due to the lower phosphorescence intensities with high $\left[\mathrm{O}_{2}\right]$ (little light reaching the photomultiplier tube). $\mathrm{O}_{2}$ concentration was calculated using, $1 / \tau=1 / \tau^{\mathrm{o}}+k_{q}\left[\mathrm{O}_{2}\right]$.

Dissolved $\mathrm{O}_{2}$ is expressed in $\mathrm{mm} \mathrm{Hg}, \mathrm{ml} \mathrm{O}_{2} / \mathrm{L}, \mathrm{mg} \mathrm{O}_{2} /$ $\mathrm{L}$, or $\mathrm{mmol} / \mathrm{L}(\mathrm{mM})$. For conver-sion: A partial pressure of oxygen $\left(\mathrm{PO}_{2}\right)$ of $1.0 \mathrm{~mm} \mathrm{Hg}=0.03 \mathrm{ml} \mathrm{O}_{2} / \mathrm{L} ; 1.0 \mathrm{ml} \mathrm{O}_{2} /$ $\mathrm{L}=1.4276 \mathrm{mg} \mathrm{O}_{2} / \mathrm{L} ; 1.0 \mathrm{mg} \mathrm{O}_{2} / \mathrm{L}=1000 / 32 \mu \mathrm{M}$. In freshwater at $760 \mathrm{~mm} \mathrm{Hg}$ and $20^{\circ} \mathrm{C}$, dissolved $\left[\mathrm{O}_{2}\right]$ is $9.1 \mathrm{mg} / \mathrm{L}$, or $284 \mu \mathrm{M}$. Using a Clark electrode, the $\mathrm{PO}_{2}$ of our reaction mixture (PBS with $10 \mathrm{mM}$ glucose, $3.0 \mu \mathrm{M}$ Pd phosphor and $0.5 \%$ fat-free bovine serum albumin) was 170.5 $[ \pm 6.6] \mathrm{mm} \mathrm{Hg}(\mathrm{n}=4)$, or $228[ \pm 9] \mu \mathrm{M}$. The $56 \mathrm{~mm} \mathrm{Hg}$ difference between $\left[\mathrm{O}_{2}\right]$ in freshwater and the Pd solution reflects the effect of salinity on dissolved $\mathrm{O}_{2}$.

\section{Serum IFN- $\gamma$ and aminotransferases}

Serum IFN- $\gamma$ levels were determined using a sandwich ELISA DuoSet ELISA Develop-ment (mouse IFN- $\gamma$ ) kit (R\&D Systems, Minneapolis, MN), according to manufacturer protocols. IFN- $\gamma$ concentrations (in $\mathrm{pg} / \mathrm{ml}$ ) were extrapolated from a standard curve generated in parallel 

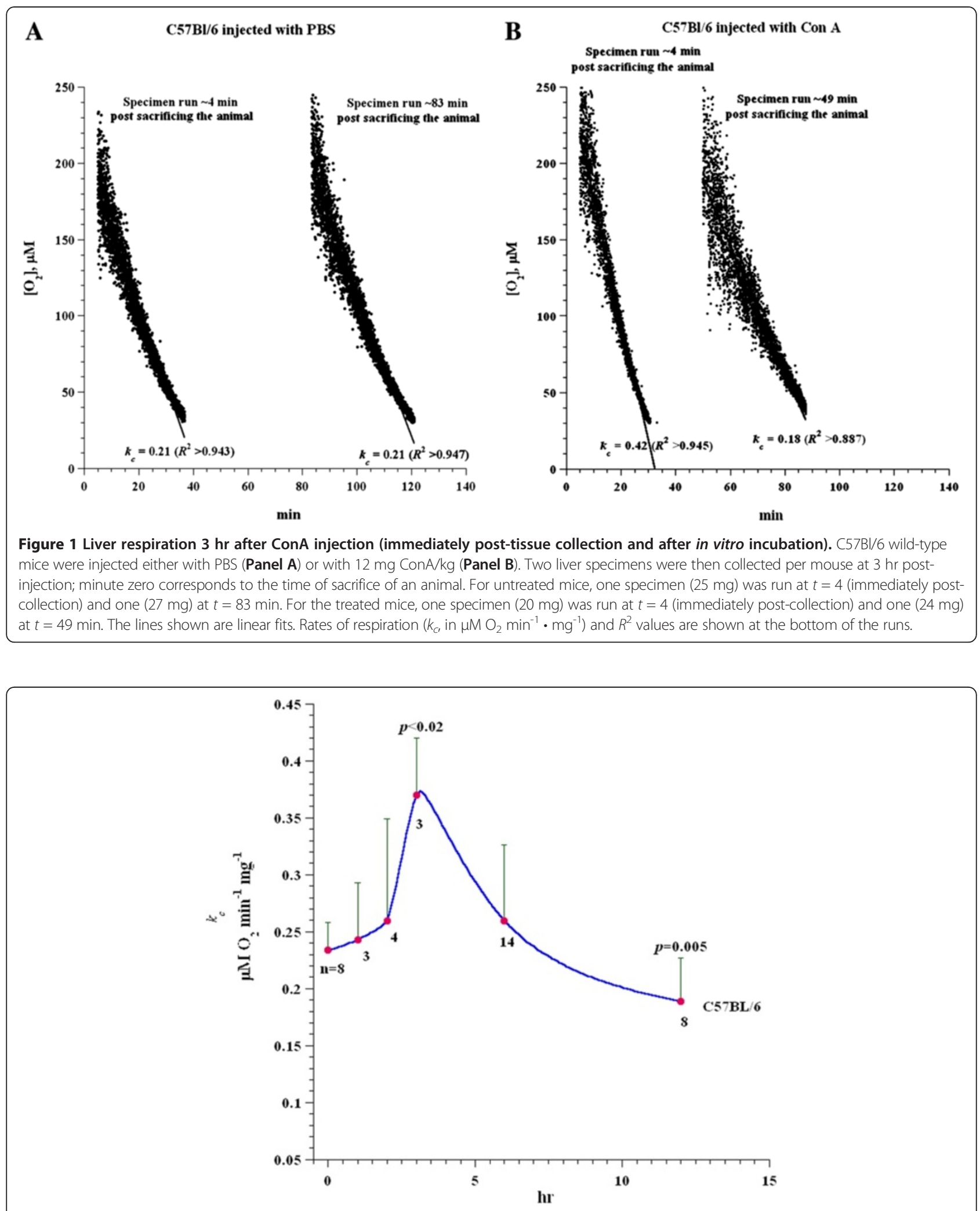

Figure 2 Time-dependent changes in liver respiration in ConA hepatitis in C57BI/6 mice. C57BI/6 mice (wild-type) were injected with PBS or $12 \mathrm{mg}$ ConA $/ \mathrm{kg}$. Liver tissue specimens were then collected at the indicated timepoints and processed for $\mathrm{O}_{2}$ measurements. Values shown are the mean $( \pm \mathrm{SD})$, with the values of " $\mathrm{n}$ " underneath each timepoint. The p-values at 3 and $12 \mathrm{hr}$ (compared to $0 \mathrm{hr}$ ) are also shown; remaining values were insignificant. 
Table 1 Liver tissue respiration in samples harvested from ConA-treated mice after $12 \mathrm{hr}$

\begin{tabular}{|c|c|c|c|}
\hline \multirow[t]{2}{*}{ Strain } & \multirow[t]{2}{*}{ Treatments } & \multicolumn{2}{|c|}{$\begin{array}{c}k_{\mathrm{c}} \\
\left(\mu \mathrm{M} \mathrm{O}_{2} \mathrm{~min}^{-1} \cdot \mathrm{mg}^{-1}\right)\end{array}$} \\
\hline & & mean \pm SD $(n)$ & range \\
\hline \multirow[t]{2}{*}{ C57BI\6 (wild-type) } & PBS $(300 \mu \mathrm{l})$ & $0.26 \pm 0.04(5)$ & $0.22-0.32$ \\
\hline & $\overline{C o n A}(12 \mathrm{mg} / \mathrm{kg})$ & ${ }^{*} 0.18 \pm 0.03(5)$ & $0.13-0.20$ \\
\hline
\end{tabular}

" $\mathrm{n}$ " represents number of independent experiments. *Value significantly different from control at $\mathrm{p} \leq 0.005$.

using kit-provided recombinant IFN- $\gamma$. The level of sensitivity of the kit was $20 \mathrm{pg} / \mathrm{ml}$.

Serum alanine aminotransferase (ALT) activity was determined on a Beckman Coulter Synchron ${ }^{\circledR}$ System (Brea, CA); $150 \mu \mathrm{l}$ serum/mouse were used in a reaction that contained L-alanine, $\alpha$-ketoglutarate, NADH and lactate dehydrogenase. NADH oxidation, calculated from the change in absorbance at $340 \mathrm{~nm}$, is proportional to the transaminase activity and the basis for the calculation of ALT activity/sample. The level of sensitivity of the assay was $5 \mathrm{IU} / \mathrm{L}$. Serum aspartate aminotransferase (AST) activity was determined as above, in a reaction that contained L-aspartate, $\alpha$-ketoglutarate, NADH, and malate dehydrogenase. The level of sensitivity of the assay was $5 \mathrm{IU} / \mathrm{L}$.

\section{Intracellular caspase activity}

Liver specimens $\left(40-55 \mathrm{mg}\right.$ ) were incubated at $37^{\circ} \mathrm{C}$ in oxygenated $\mathrm{KH}$ buffer containing $74 \mu \mathrm{M}$ Ac-DEVD-AMC with and without $43 \mu \mathrm{M}$ zVAD-fmk (final volume $=0.5 \mathrm{ml}$ ) for $30 \mathrm{~min}$. At the end of the incubation period, the suspension was sonicated on ice for $60 \mathrm{sec}$ and passed 10 times through a 27-gauge needle. The cleavage reaction was quenched with tissue disruption, as caspases became inactive due to the dilution. The supernatants were then collected by centrifugation $\left(\sim 12300 \times g\right.$ for $\left.15 \mathrm{~min}, 25^{\circ} \mathrm{C}\right)$, separated via HPLC and analyzed for free AMC as described below [7].

\section{HPLC}

The analysis was performed on a Waters 1525 reversedphase HPLC system (SpectraLab Scientific Inc, Alexandria, VA) that consisted of a manual injector, pump, and fluorescence detector. The excitation wavelength used was

Table 2 Liver tissue respiration in tissues collected from ConA-treated C57BI/6 wild-type and IFN- $\gamma^{-/-}$mice $7 \mathrm{hr}$ after treatment

\begin{tabular}{|c|c|c|}
\hline Strain & Treatment & $\begin{array}{c}k_{\mathrm{c}} \\
\left(\mu \mathrm{M} \mathrm{O}_{2} \mathrm{~min}^{-1} \cdot \mathrm{mg}^{-1}\right)\end{array}$ \\
\hline$C 57 B \backslash \backslash 6$ & PBS $(180 \mu \mathrm{l})$ & $0.27 \pm 0.13(11)$ \\
\hline C57B/ 6 & ConA (12 mg/kg) & $0.26 \pm 0.07(3)$ \\
\hline C57BI\6 IFN- $\gamma^{-1-}$ & ConA (12 mg/kg) & $0.25 \pm 0.10(3)$ \\
\hline
\end{tabular}

" $n$ " represents number of independent experiments. Values shown are mean \pm SD.
$380 \mathrm{~nm}$ and the emission wavelength $460 \mathrm{~nm}$. Solvent A was HPLC-grade $\mathrm{CH}_{3} \mathrm{CN}: \mathrm{H}_{2} \mathrm{O}[1: 3, \mathrm{v} / \mathrm{v}]$, and Solvent B was $\mathrm{dH}_{2} \mathrm{O}$ (isocratic). The Ultrasphere IP column $(4.6 \times$ $250 \mathrm{~mm}$, Beckman, Brea) was operated at $25^{\circ} \mathrm{C}$ at $1.0 \mathrm{ml} /$ $\min (0.5 \mathrm{ml} / \mathrm{min}$ of each pump). The run time was $30 \mathrm{~min}$.

\section{Phenotyping of infiltrating mononuclear cells by} fluorescence activated cell sorting analysis (FACS) analysis Liver fragments were placed in RPMI with $5 \%$ fetal calf serum (FCS; Hyclone, Logan, UT) and $25 \mathrm{mM}$ HEPES, and passed through 200-gauge stainless steel mesh. The pellets were then collected by centrifugation $(\sim 500 \times g$ at $4^{\circ} \mathrm{C}$ for $\left.10 \mathrm{~min}\right)$, suspended in $40 \%$ Percol $^{\circledR}$, and layered on the top of $70 \%$ Percol $^{\circledR}$. The solutions were then centrifuged at $\sim 100 \times g$ and $25^{\circ} \mathrm{C}$ for $20 \mathrm{~min}$. The mononuclear cells were collected from the interface, washed twice with RPMI, and re-suspended in RPMI at $3 \times 10^{5} / \mathrm{ml}$.

For immunophenotyping, the fluorescent-labeled antibodies fluorescein isothiocyanate (FITC)-conjugated rat anti-mouse CD3, CD4, and CD45 and phycoerythrin (PE)-conjugated rat anti-mouse CD8, NK T, and CD11b were used (all were purchased from eBioscience, San Diego, CA). To avoid non-specific binding, $1 \times 10^{6}$ cells/ mouse were incubated with $20 \%$ FCS for $10 \mathrm{~min}$ at $4^{\circ} \mathrm{C}$. The cells were then gently washed with PBS supplemented with 5\% FCS and the resultant pellet treated with $100 \mu \mathrm{l}$ aliquots (from $3 \mu \mathrm{g} / \mathrm{ml}$ stocks) each of a given pair of antibodies, i.e., FITC-anti-CD4 + PE-anti-CD8, FITCanti-CD3 + PE-anti-NK/NKT, or FITC-anti-CD45 + PEanti-CD11b. The cells were then incubated for $35 \mathrm{~min}$ at $4^{\circ} \mathrm{C}$ in the dark. Thereafter, the cells were washed twice with PBS-FCS and then re-suspended at $10^{6}$ cells/tube in $0.5 \mathrm{ml}$ PBS-FCS. Samples were then analyzed via flow cytometry using a FACSort system (Becton Dickinson, Franklin Lakes, NJ) and associated CellQuest software. A minimum of 10,000 events per sample were acquired.

\section{Statistical analysis}

The Student's $t$-test of difference of means was used to compare treated and untreated samples. The threshold of significance was taken to be $\mathrm{p}<0.05$.

\section{Results}

Hepatocyte oxygen consumption in C57BI/6 mice treated with ConA

Figure 1 depicts a representative experiment of hepatocyte respiration in ConA-treated and untreated $\mathrm{C} 57 \mathrm{Bl} / 6$ mice. One mouse was injected with PBS (Panel A) and one with $12 \mathrm{mg}$ ConA/kg per body weight (Panel B). Two liver specimens were collected from each mouse $3 \mathrm{hr}$ after injection. For the untreated mouse, one specimen was run immediately and one after $\sim 83 \mathrm{~min}$ of in vitro incubation at $37^{\circ} \mathrm{C}$ in Krebs-Henseleit solution gassed with $95 \% \mathrm{O}_{2}: 5 \%$ $\mathrm{CO}_{2}$. The rate of respiration $\left(k_{c}, \mu \mathrm{M} \mathrm{O} \mathrm{Omin}^{-1} \cdot \mathrm{mg}^{-1}\right)$ in 


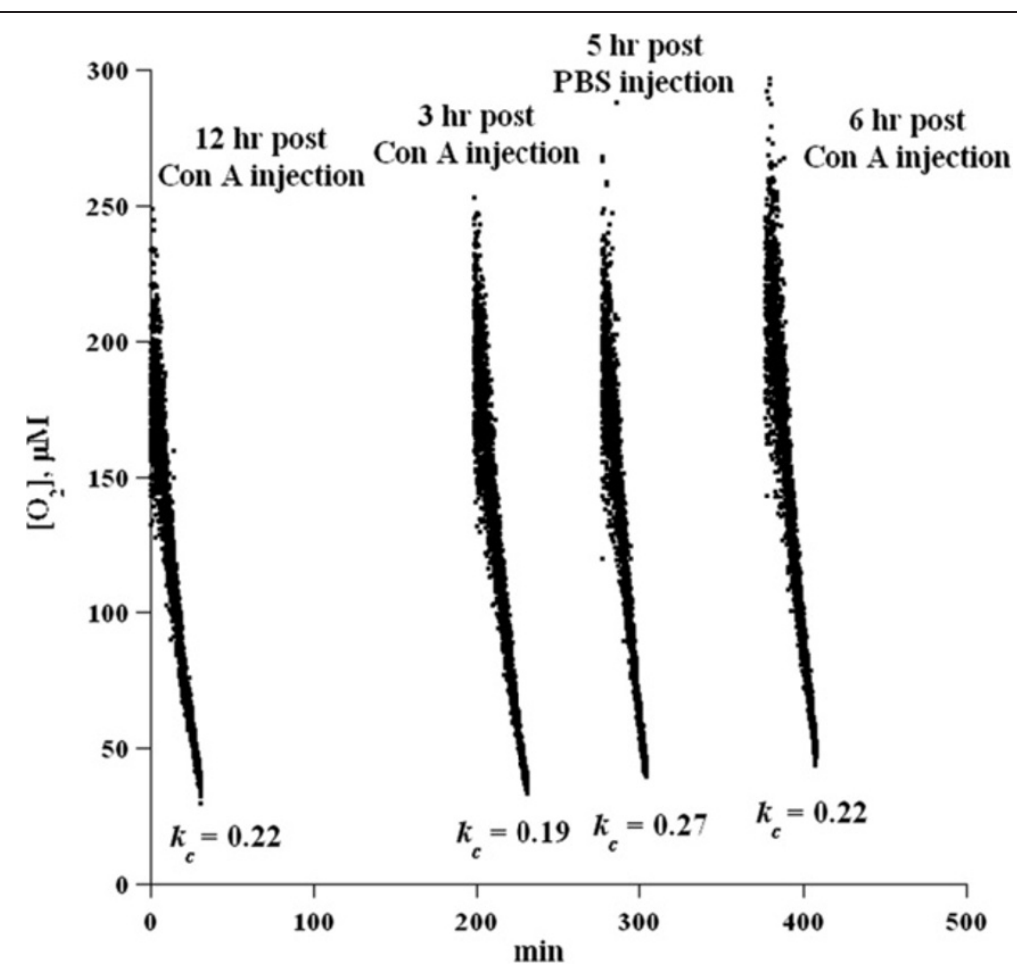

Figure 3 Time-dependent changes in liver respiration in ConA hepatitis in C57BI/6 IFN- $\boldsymbol{\gamma}^{-/}$mice. Mice were injected with $20 \mathrm{mg}$ ConA/kg and liver specimens (24-29 mg) were collected for $\mathrm{O}_{2}$ measurements at 3, 6, and $12 \mathrm{hr}$ post-injection. Control mice were injected with PBS. Rates of respiration $\left(k_{c}\right.$ in $\left.\mu \mathrm{M} \mathrm{O}_{2} \mathrm{~min}^{-1} \cdot \mathrm{mg}^{-1}\right)$ are shown at the bottom of the runs. All four runs were performed on one instrument. One animal was sacrificed at-a-time in the following sequence: $12 \mathrm{hr}$ post-injection, $3 \mathrm{hr}$ post-injection, PBS, and then $6 \mathrm{hr}$ post-injection. Minute zero corresponds to sacrifice of the first animal.

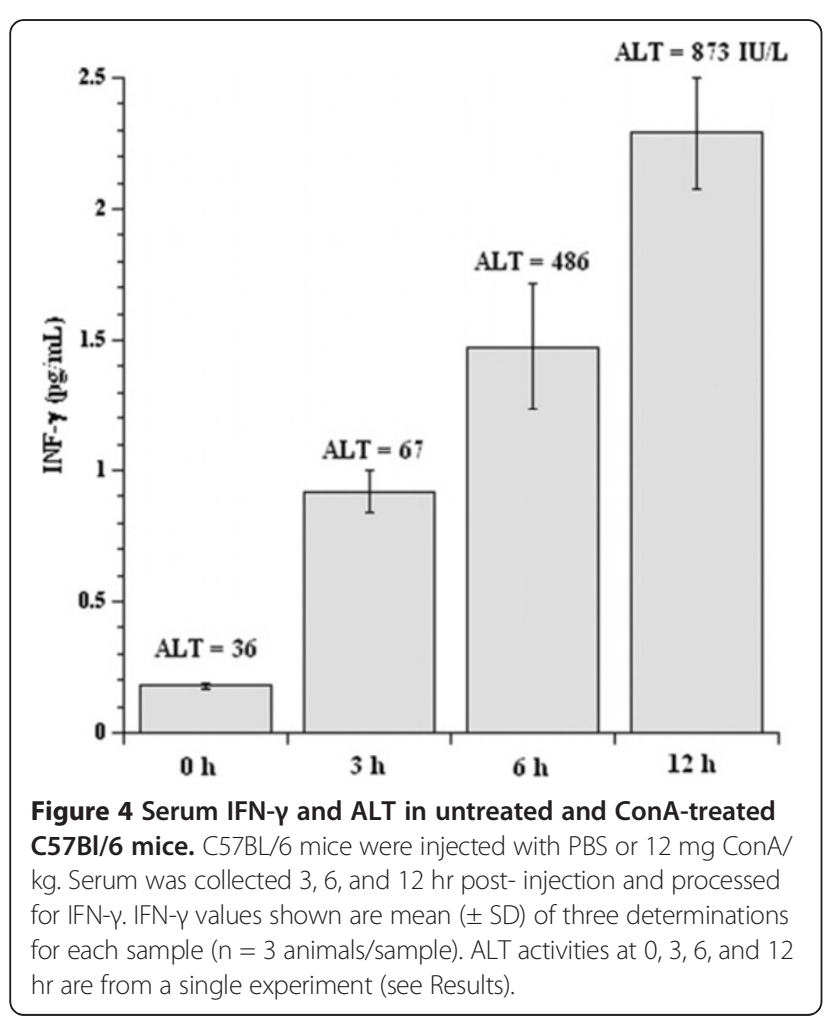

both specimens was 0.21 , confirming stability of the liver specimens in vitro $[8,9]$. For the treated mouse, one specimen was also run immediately post collection and one after $\sim 49 \mathrm{~min}$ of in vitro incubation as above. The values of $k_{c}$ were 0.42 (2-fold increment) and 0.18 (similar to the control) respectively. These results demonstrate accelerated rate of liver tissue $\mathrm{O}_{2}$ consumption $3 \mathrm{hr}$ after ConA injection. In another experiment, the values of $k_{c}$ for the untreated mouse were 0.20 at $t=5 \mathrm{~min}$ (immediately post specimen collection) and 0.24 at $t=83 \mathrm{~min}$ (after $83 \mathrm{~min}$ incubation in vitro as above); the corresponding values for the treated mouse were 0.34 at $t=3 \mathrm{~min}$ (a 70\% increment) and 0.14 at $t=59 \mathrm{~min}$. In a third experiment, the values of $k_{c}$ for the untreated mouse were 0.25 at $t=5 \mathrm{~min}$ and 0.23 at $t=58 \mathrm{~min}$; corresponding values for the treated mouse were 0.34 at $t=5 \mathrm{~min}$ (36\% increment) and 0.20 at $t=75$ min. Thus, for untreated mice, values of $k_{c}$ (mean $\pm \mathrm{SD}$ ) were $0.22 \pm 0.02(\mathrm{n}=6)$. For treated mice, values of $k_{c}$ for specimens run immediately were $0.37 \pm 0.05(\mathrm{n}=3$, a $68 \%$ increase, $\mathrm{p}=0.015$ ) and for specimens incubated in vitro before the run, $0.17 \pm 0.03(\mathrm{n}=3$, a $54 \%$ less, $\mathrm{p}=0.005)$.

In a total of eight independent experiments, the values of $k_{c}$ in untreated mice were $0.234 \pm 0.024(\mathrm{n}=8)$ and in treated mice $3 \mathrm{hr}$ after ConA injection $(12 \mathrm{mg} / \mathrm{kg}) 0.300 \pm$ $0.066(\mathrm{n}=8, \mathrm{p}<0.05)$. The variability in the values of $k_{c}$ in 
Al-Shamsi et al. BMC Gastroenterology 2013, 13:6

Page 7 of 13

http://www.biomedcentral.com/1471-230X/13/6

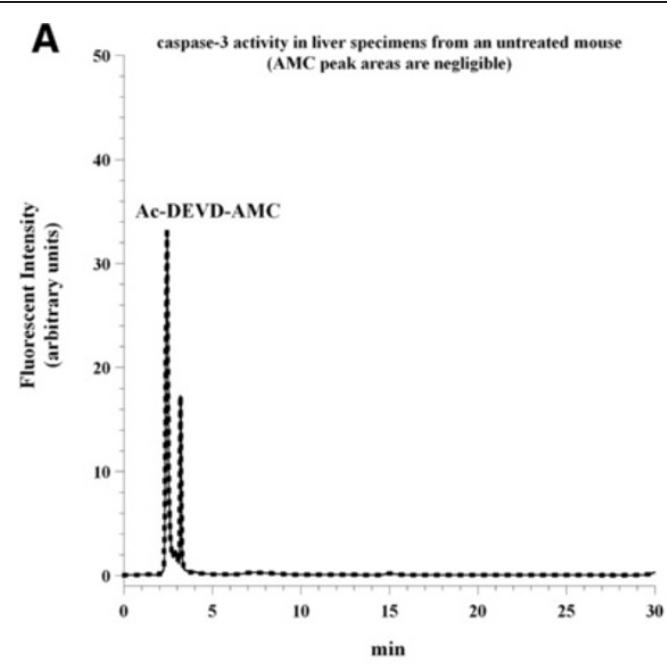

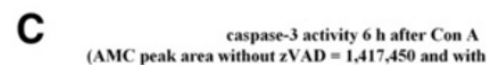
(AMC peak area without $z$ WAD $=1,417,450$ and with $z$ NAD $=691,348$ )
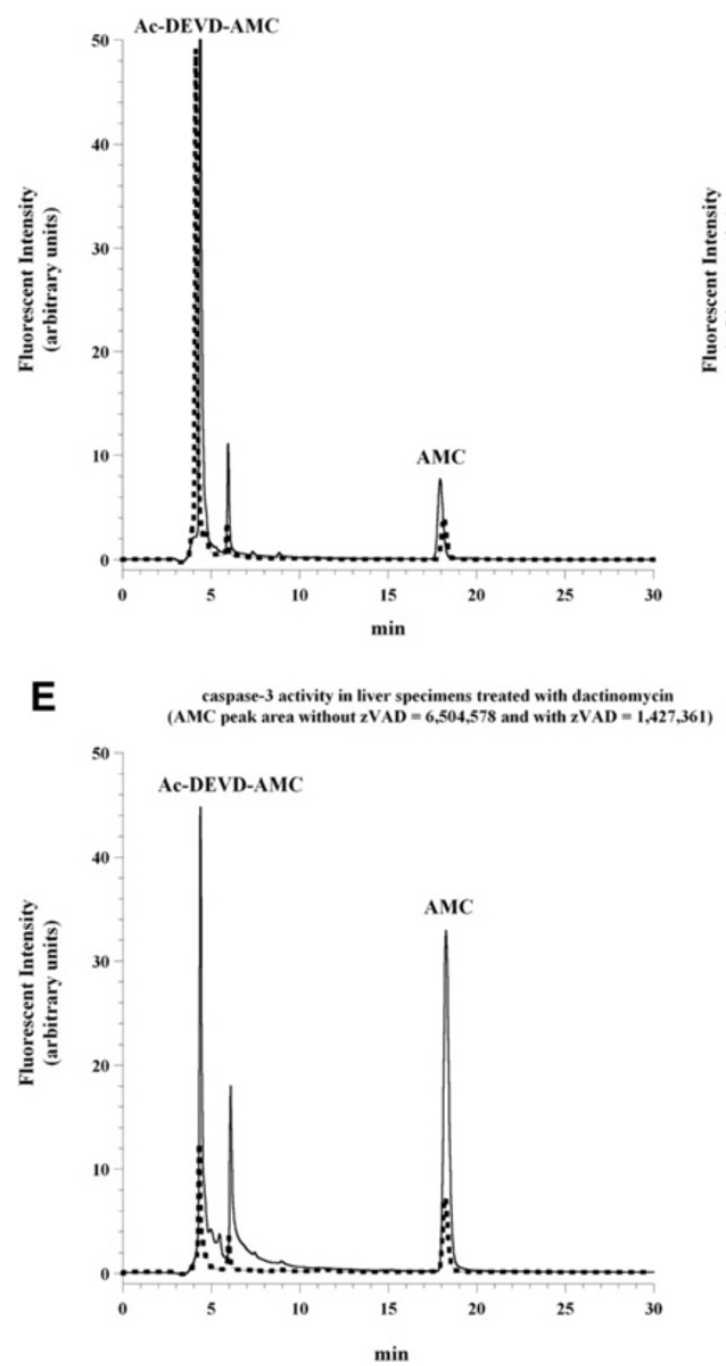

Figure 5 (See legend on next page.)

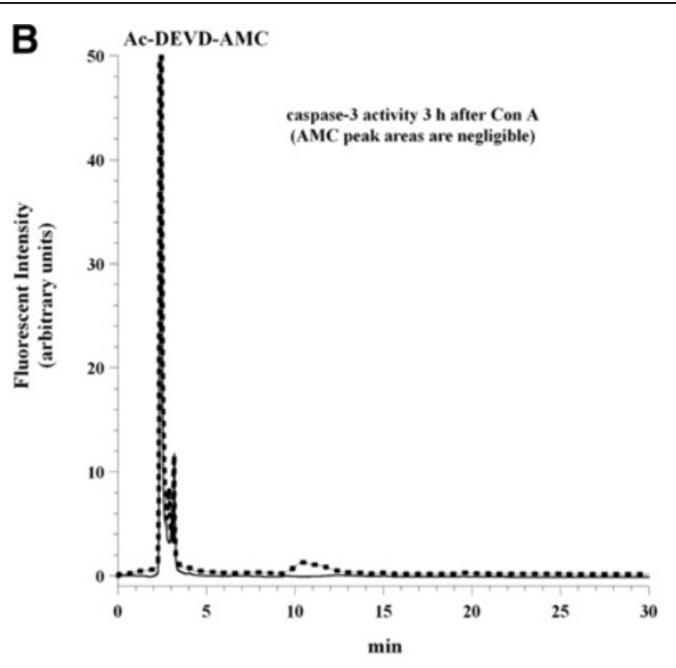

D caspase-3 activity 12 hater Con (AMC peak area without $\mathrm{ZVAD}=\mathbf{2 , 0 2 8 , 3 8 8}$ and with $\mathrm{zVAD}=1,252,429$ )

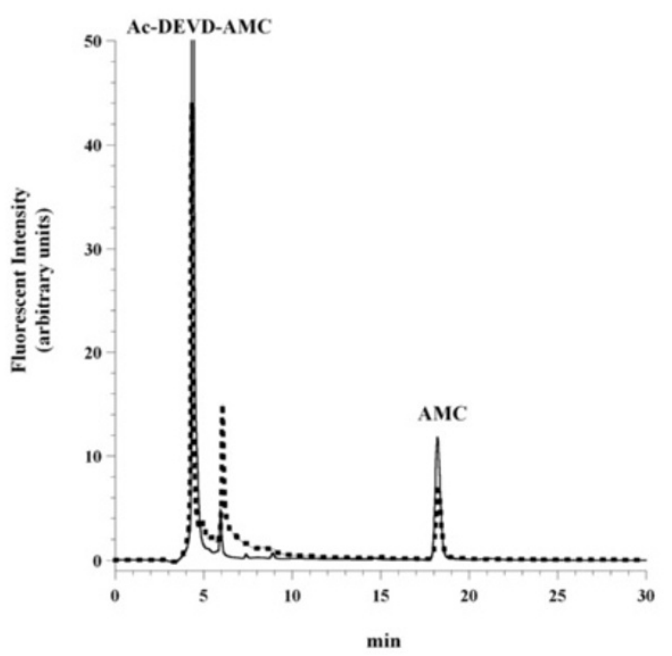


(See figure on previous page.)

Figure 5 Liver tissue caspase activation in untreated and ConA-treated C57BI/6 mice. C57BL/6 mice were injected with (A) PBS or (B-D) 12 mg ConA/kg. Liver specimens were collected (B) 3, (C) 6, or (D) $12 \mathrm{hr}$ post-injection and processed immediately for caspase activity. For each condition, liver specimens were incubated at $37^{\circ} \mathrm{C}$ in oxygenated $\mathrm{KH}$ buffer in the presence of $74 \mu \mathrm{M}$ Ac-DEVD-AMC with (dashed line) and without (solid line) $43 \mu \mathrm{M}$ zVAD-fmk for $30 \mathrm{~min}$. The cleavage reaction was quenched with tissue disruption. The supernatants were separated via HPLC and analyzed for AC-DEVD-AMC $\left(R_{\mathrm{t}} \sim 3 \mathrm{~min}\right)$ and free AMC ( $\left.R_{\mathrm{t}} \sim 18 \mathrm{~min}\right)$ peaks as described in the Materials and Methods. In Panel E, liver specimens were treated in vitro with $8 \mu \mathrm{M}$ dactinomycin for 60 min prior to the addition of Ac-DEVD-AMC with (dashed line) and without (solid line) zVAD-fmk.

treated mice (coefficient of variation $=\sim 22 \%$ in ConAinjected mice compared to $\sim 10 \%$ in untreated mice) likely reflected the heterogeneity of the liver involvement and the variation of its progress with time.

Changes in liver tissue respiration during the course of ConA-induced hepatitis are summarized in Figure 2. As discussed above, the rate of respiration $\left(k_{\mathrm{c}}\right)$ significantly increased at $3 \mathrm{hr}(\mathrm{p}<0.02)$ and decreased at $12 \mathrm{hr}$ $(\mathrm{p}=0.005$, see also Table 1$)$. By contrast, the values of $k_{\mathrm{c}}$ at 1,2 , and $6 \mathrm{hr}$ after ConA injection did not significantly differ from untreated mice (also see Table 2). Liver tissue respiration was not altered by in vitro addition of ConA (Additional file 1: Figure S2).

\section{Hepatocyte oxygen consumption in $\mathrm{C} 57 \mathrm{BI} / 6 \mathrm{IFN}-\gamma^{-/-}$mice treated with ConA $/ \mathrm{kg}$}

$\mathrm{C} 57 \mathrm{Bl} / 6 \mathrm{IFN}-\gamma^{-/-}$mice were injected with $20 \mathrm{mg}$ ConA $/ \mathrm{kg}$ or PBS and then liver pieces were collected
3,6 , and $12 \mathrm{hr}$ post-injection. The mean $k_{\mathrm{c}}$ value (in $\mu \mathrm{M} \mathrm{O}_{2} \mathrm{~min}^{-1} \cdot \mathrm{mg}^{-1}$ ) for uninjected mouse was 0.27 . The corresponding $k_{\mathrm{c}}$ values for injected mice at 3,6 , and $12 \mathrm{hr}$ post-injection were $0.19,0.22$, and 0.22 , respectively (Figure 3 and Table 2). Of note, additions of exogenous IFN- $\gamma(10,50$ or $100 \mathrm{ng} / \mathrm{mL})$ resulted in inhibition of liver tissue respiration (Additional file 1: Figure S3).

\section{Serum IFN- $\gamma$ in C57BI/6 mice treated with ConA}

Serum IFN- $\gamma$ levels were determined in untreated and ConA-treated (12 mg/kg) C57Bl/6 mice at 0, 3, 6, and $12 \mathrm{hr}$ post-injection. The results of three independent experiments are shown in Figure 4. Relative to the values seen in untreated animals, elevated levels of IFN- $\gamma$ were noted at $3 \mathrm{hr}$ after ConA injection, and these increased with time.

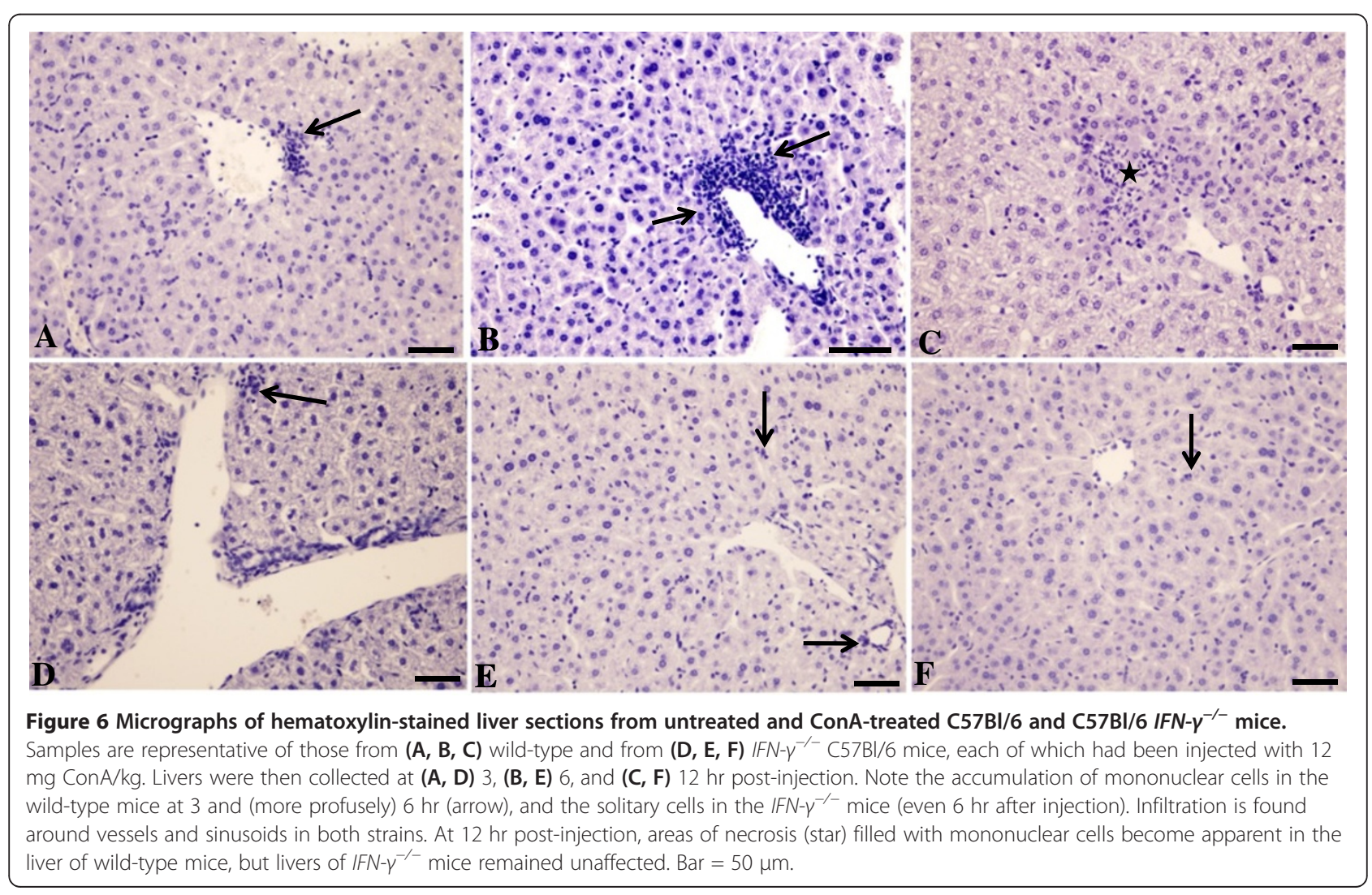


Figure 7 Electron micrographs of hepatocytes from untreated and ConA-treated C57BI/6 mice. Hepatocytes were obtained from (A) normal untreated and ConA-injected C57BI/6 mice (B) 3 and (C) $6 \mathrm{hr}$ post-injection. A representative micrograph is shown for each timepoint. Note the nuclei and mitochondria in each of the micrographs are normal. Bar $=0.3 \mu \mathrm{m}$.

\section{Serum ALT and AST in C57BI/6 and C57BI/6 IFN- $\gamma^{-/-}$mice treated with ConA}

Serum ALT activity was determined in untreated and ConA-treated $(12 \mathrm{mg} / \mathrm{kg}) \mathrm{C} 57 \mathrm{Bl} / 6$ mice at $0,3,6$, and 12 $\mathrm{hr}$ post-injection. Elevated levels of ALT were noted at $3 \mathrm{hr}$ after ConA and these increased with time (Figure 4). In three independent experiments, serum ALT levels $12 \mathrm{hr}$ after ConA were $440 \pm 393 \mathrm{IU} / \mathrm{L}($ mean $\pm \mathrm{SD}, \mathrm{n}=3$ ) and AST $768 \pm 528(\mathrm{n}=3)$.

For $\mathrm{C} 57 \mathrm{Bl} / 6 \mathrm{IFN}-\gamma^{-1-}$ mice, ATL activities were 45,96 , and $32 \mathrm{IU} / \mathrm{L}$ at the 0,3 and $6 \mathrm{hr}$ time points, respectively. The corresponding values for AST were 157, 259, and 228 IU/L. At $12 \mathrm{hr}$, the values of ALT were $172 \pm 154 \mathrm{IU} / \mathrm{L}$ $(\mathrm{n}=3)$ and AST $394 \pm 198 \mathrm{IU} / \mathrm{L}(\mathrm{n}=3)$.

Serum ALT activities in PBS-treated $\mathrm{C} 57 \mathrm{Bl} / 6$ mice at 0 and $12 \mathrm{hr}$ were, respectively, 30 and $30 \mathrm{U} / \mathrm{L}$; serum IFN$\gamma$ levels in PBS-treated C57Bl/6 mice at 0 and $12 \mathrm{hr}$ were non-measurable. Serum ALT activities in PBS-treated $\mathrm{C} 57 \mathrm{Bl} / 6 \mathrm{IFN}-\gamma^{-/-}$mice at 0 and $12 \mathrm{hr}$ were, respectively, 35 and $46 \mathrm{U} / \mathrm{L}$.

\section{Caspase activation in C57BI/6 mice treated with ConA}

Caspase activity in liver tissue was monitored in untreated and ConA-treated $(12 \mathrm{mg} / \mathrm{kg})$ mice at 3, 6, and $12 \mathrm{hr}$ post-injection, using the caspase- 3 substrate analogue AcDEVD-AMC. Liver specimens were incubated with 74 $\mu \mathrm{M}$ Ac-DEVD-AMC in the presence and absence of the pan-caspase inhibitor zVAD-fmk. Caspases cleaved AcDEVD-AMC, releasing the fluorogenic moiety AMC; post-sample disruption, AMC was separated on HPLC $\left(R_{\mathrm{t}} \sim 18 \mathrm{~min}\right)$ and detected by fluorescence.

AMC peak was neither detected in the untreated mouse (Figure 5A) nor in the ConA-treated mouse at 3 hr (Figure 5B). By contrast, an AMC peak was detected at 6 and $12 \mathrm{hr}$ after ConA injection. At $6 \mathrm{hr}$ (Figure 5C), the AMC peak area (arbitrary units) without zVAD-fmk was 1,417,450 and with zVAD-fmk was 691,348 ( 51\% inhibition). At $12 \mathrm{hr}$ (Figure 5D), the AMC peak area without zVAD-fmk was 2,028,388 and with zVAD-fmk $1,252,429$ ( $\sim 38 \%$ inhibition). These results demonstrate rapid uptake and hydrolysis of Ac-DEVD-AMC by active caspases in hepatocytes. Residual caspase activity in the presence of zVAD-fmk was due to the simultaneous addition of Ac-DEVD-AMC (added in excess) and zVAD-fmk. The free AMC moieties were negligible in experiments where Ac-DEVD-AMC was added $10 \mathrm{~min}$ after addition of zVAD-fmk (data not shown). In another 

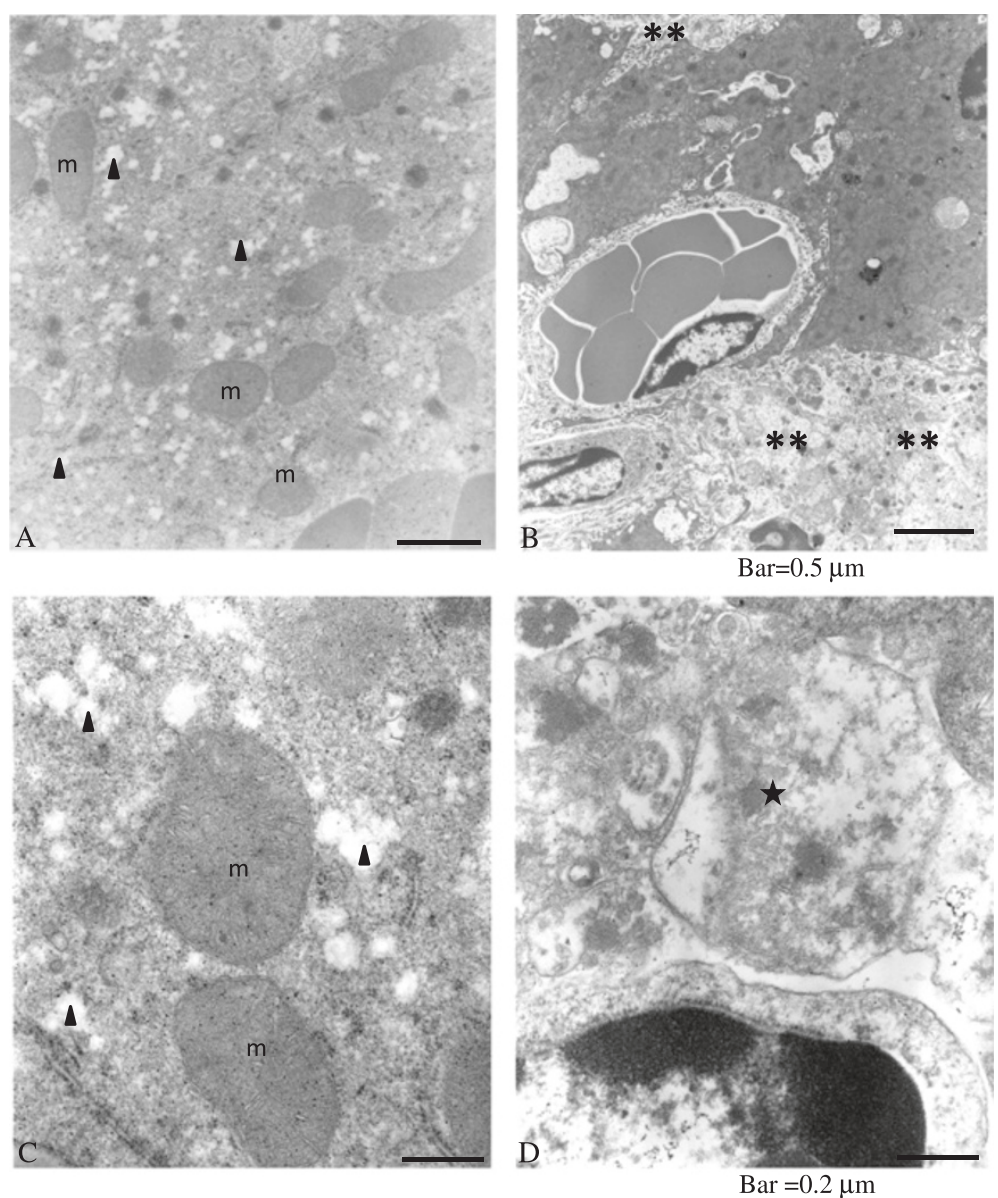

Figure 8 Electron micrographs of sections of murine liver taken $12 \mathrm{hr}$ after intravenous injection of $12 \mathrm{mg} \mathrm{ConA} / \mathrm{kg}$. Representative

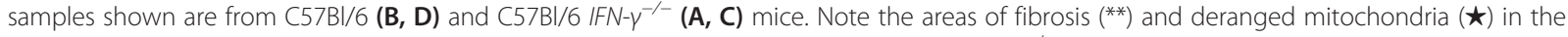
liver of $\mathrm{C} 57 \mathrm{Bl} / 6$ mice. With the exception of fatty infiltrates $(\mathbf{\Lambda})$, the liver of the C57BI/6 IFN- $\gamma^{-1-}$ mice appears normal with intact mitochondria (m). Bars: $A-B=0.5 \mu \mathrm{m} ; C-D=0.2 \mu \mathrm{m}$.

two independent experiments, the AMC peak was detected at $3 \mathrm{hr}$ and increased linearly at $12 \mathrm{hr}\left(R^{2}>0.999\right.$ and $>0.995)$.

For comparison, liver tissue specimens were also treated in vitro with $8 \mu \mathrm{M}$ dactinomycin, a cytotoxic agent that intercalates between DNA base pairs and activates caspases [7]. The AMC peak area in the presence of dactinomycin alone was 6,504,578 and in the presence of dactinomycin + zVAD-fmk was 1,427,361 (78\% inhibition, Figure 5E).

\section{Light and electron microscopy of tissues from C57BI/6 and $\mathrm{C} 57 \mathrm{BI} / 6 \mathrm{IFN}-\gamma^{-/-}$mice}

Figure 6 shows the liver histology in ConA-injected $\left(12 \mathrm{mg} / \mathrm{kg}\right.$ ) $\mathrm{C} 57 \mathrm{Bl} / 6$ and $\mathrm{C} 57 \mathrm{Bl} / 6 \mathrm{IFN}-\gamma^{-1-}$ mice at 3, 6 and $12 \mathrm{hr}$. In C57Bl/6 mice, mononuclear cell accumulation around blood vessels was noted 3 and $6 \mathrm{hr}$ after the ConA administration. More prominent mononuclear cell infiltration around blood vessels and into the tissues and areas of necrosis were noted $12 \mathrm{hr}$ after the injection in
$\mathrm{C} 57 \mathrm{Bl} / 6$, but not in $\mathrm{C} 57 \mathrm{Bl} / 6 \mathrm{IFN}-\gamma^{-/-}$, mice. Overall, the liver architecture was relatively preserved in the $\mathrm{C} 57 \mathrm{BL} / 6$ IFN- $\gamma^{-1-}$ mice.

Electron micrographs of the hepatocytes showed a normal presence of nuclei and mitochondria in untreated and ConA-treated $(12 \mathrm{mg} / \mathrm{kg}) \mathrm{C} 57 \mathrm{Bl} / 6$ mice at 3 and $6 \mathrm{hr}$ after injection (Figure 7).

The histopathology of liver sections obtained from uninjected or PBS-injected $\mathrm{C} 57 \mathrm{Bl} / 6$ and from uninjected or PBS-injected $\mathrm{C} 57 \mathrm{Bl} / 6 \mathrm{IFN}-^{-1-}$ mice showed an absence of infiltrations in any of the sections examined and prominent sinusoids in the livers of the PBS-injected hosts from both strains (Additional file 1: Figure S4).

Electron micrographs of sections of murine liver taken $12 \mathrm{hr}$ after intravascular injection of ConA $(12 \mathrm{mg} / \mathrm{kg})$ from $\mathrm{C} 57 \mathrm{Bl} / 6$ and $\mathrm{C} 57 \mathrm{Bl} / 6 \mathrm{IFN}^{-} \gamma^{-1-}$ mice are shown in Figure 8. Areas of fibrosis and deranged mitochondria were prominent in the liver of $\mathrm{C} 57 \mathrm{Bl} / 6$ mice. With the exception of fatty infiltrates, the liver of $\mathrm{C} 57 \mathrm{Bl} / 6 \mathrm{IFN}-\gamma^{-/-}$ mice appeared normal - with intact mitochondria. 


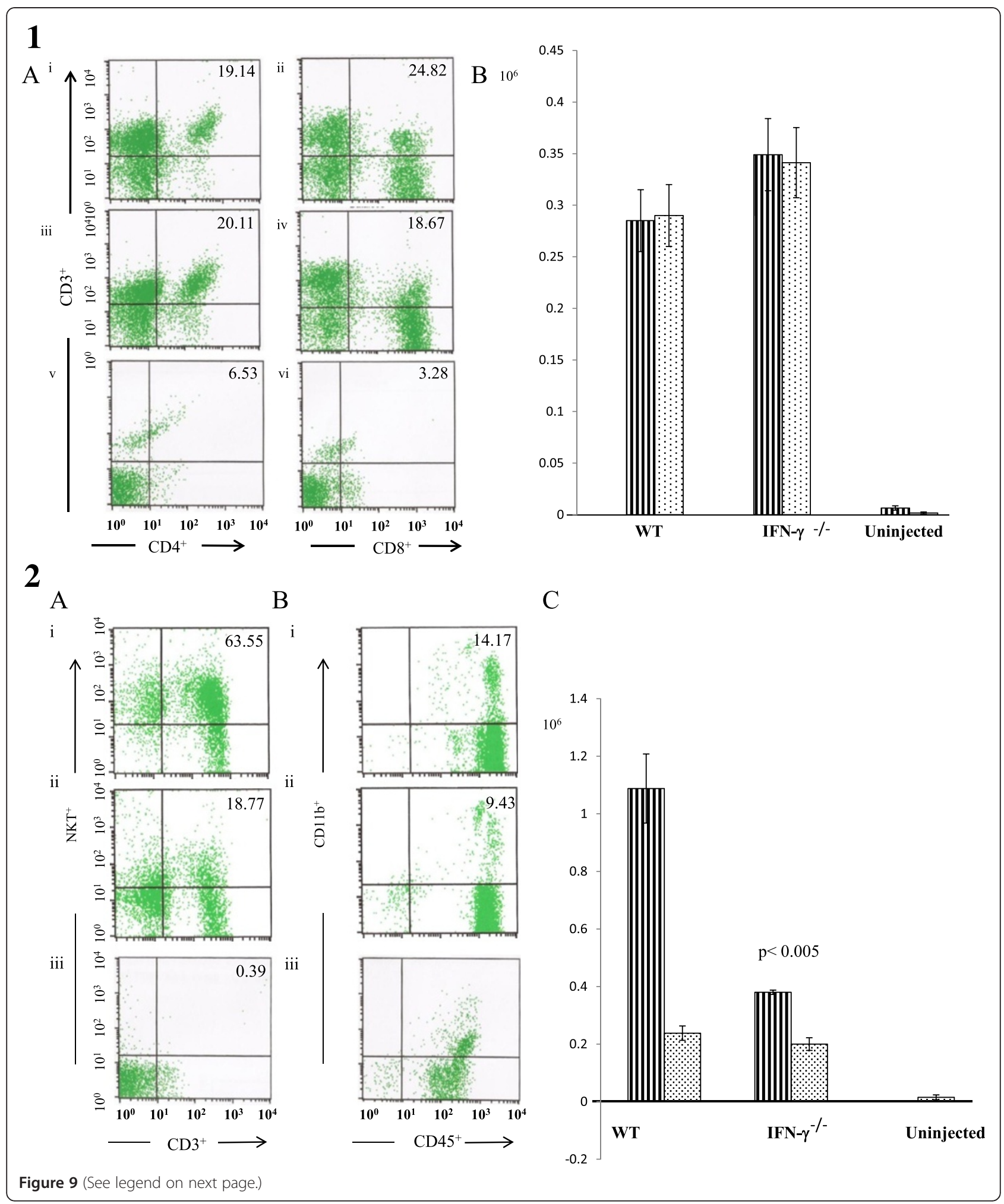


(See figure on previous page.)

Figure 9 FACS analysis. Panel $1 \mathrm{~A}$ (FACS analysis of $\mathrm{CD}^{+} \mathrm{CD}^{+}$and $\mathrm{CD} 3^{+} \mathrm{CD} 8^{+}$cells of liver samples): Representative liver samples from $\mathrm{C} 57 \mathrm{BI} / 6$ wild-type (i and ii) and IFN- $\gamma^{-/-}$on C57BI/6 background (iii and iv) mice $12 \mathrm{hr}$ after injection with $12 \mathrm{mg} / \mathrm{kg}$ of ConA. The number of mononuclear cells per mouse isolated from ConA injected mice was $1.5 \times 10^{6}(\mathrm{C} 57 \mathrm{BI} / 6)$ and $1.8 \times 10^{6}\left(\mathrm{C} 57 \mathrm{BI} / 6 \mathrm{IFN}-\gamma^{-/-}\right)$, respectively. The number of mononuclear cells per mouse isolated from uninjected C57Bl/6 mice was $5.0 \times 10^{4}$ ( $\mathrm{v}$ and vi). The values in the upper right corners (i-vi) are percents of CD4 ${ }^{+}$or $\mathrm{CD} 8^{+} \mathrm{T}$ cells. Panel 1B: The numbers $\left(\times 10^{6}\right)$ of $\mathrm{CD}^{+}$(lines) and $\mathrm{CD}^{+}$(dots) T cells for wild-type (WT) and IFN- ${ }^{-1-}$ mice are shown. There were no significant differences between the numbers of $\mathrm{CD}^{+}$or $\mathrm{CD}^{+} \mathrm{T}$ cells isolated from the two strains. As expected, there was near absence of these cells in the uninjected mice. Panel 2A-B (FACS analysis of $\mathrm{CD}^{+} \mathrm{NKT}^{+}$and $\mathrm{CD} 45^{+} \mathrm{CD} 11 \mathbf{b}^{+}$cells of liver samples). Note the significant number of NKT ${ }^{+}$cells (lines) present in the WT mice compared to the IFN- $\gamma^{-1-}$ mice $(p<0.005)$. There was no significant difference between the numbers of CD11 $b^{+}$cells (dots) isolated from the two strains. As expected, there was near absence of these cells in the uninjected mice.

\section{FACS analyses of cellular isolates from liver}

FACS analyses of liver homogenates prepared from $\mathrm{C} 57 \mathrm{Bl} / 6$ and $\mathrm{C} 57 \mathrm{Bl} / 6 \mathrm{IFN}-\gamma^{-/-}$mice were performed to characterize the phenotype of cellular infiltrates $12 \mathrm{hr}$ after intravenous injection of ConA (12 mg/kg). As shown in Figure 9, T-cells $\left(\mathrm{CD}^{+}, \mathrm{CD}^{+}\right)$and macrophages $\left(\mathrm{CD} 45^{+} \mathrm{CD} 11 \mathrm{~b}^{+}\right)$were present in both strains. NKT cells $\left(\mathrm{CD}^{+} \mathrm{NKT}^{+}\right)$, on the other hand, were significantly present only in the wild-type mice $(p<0.005)$. Of note, much lower number of cells was present in the uninjected $\mathrm{C} 57 \mathrm{Bl} / 6$ mice.

\section{Discussion}

Concanavalin A (ConA) is a potent inducer of inflammatory cytokines from the innate immune cells. Intravenous administration of this lectin results in progressive hepatic inflammation in mice $[1,2]$. The events commence within $2 \mathrm{hr}$ of ConA treatment, with attachment of leukocytes to the hepatic endothelium and activation of NK cells and macro-phages. At about $8 \mathrm{hr}$, lymphocytes adhere to hepatocytes. At this stage, morphological changes (e.g., cell surface blebs) on hepatocytes and endothelium - and recruitment of neutrophils to the vascular lumen - become prominent. In later stages, the sinusoidal surfaces of hepatocytes show rupture of the cell membrane and loss of cytoplasm (necrosis) [1,2]. Thus, it appears that the ConA-induced hepatic injury represents deleterious effects of inflammatory molecules released by a number of cellular sources, including Kupffer cells, NK cells, leukocytes, and endothelial cells [12,13].

Changes in liver tissue bioenergetics during the course of ConA-induced hepatitis have not been previously studied. It is unknown whether the inflammatory cytokines alter hepatocyte metabolism (e.g., inducing higher energy expenditure and requirement). A novel finding in this study is that an increase in hepatocyte $\mathrm{O}_{2}$ consumption is observed $3 \mathrm{hr}$ after ConA injection. This effect is not present in the $\mathrm{C} 57 \mathrm{Bl} / 6 \mathrm{IFN}-\gamma^{-/-}$mice, which has a milder disease. Cytokines, including IFN- $\gamma$, typically appear in the serum 2 to 3 $\mathrm{hr}$ after ConA administration [14]; the findings here are in keeping with those earlier studies (Figure 4).

A suppression of ConA-induced hepatitis is noted in the IFN $-\gamma^{-1-}$ mice (Figures 6, 8 and Additional file 1: Figure S3). Nevertheless, the precise mechanism for the up-regulation of hepatocyte mitochondrial $\mathrm{O}_{2}$ consumption by ConA treatment is unknown. This effect was noted at $3 \mathrm{hr}$ after ConA injection when the inflammatory cells were not yet prominent (Figure 6A).

Ac-DEVD-AMC is a synthetic substrate that enters the cells rapidly and is cleaved by caspases, yielding the fluorescent compound AMC [7]. Following cell disruption, any released AMC is separated via HPLC and detected by fluorescence with great sensitivity. The reduction in AMC peak areas due to the pan-caspase inhibitor zVAD-fmk confirms that intra-cellular caspases are responsible for the cleavage. As shown in Figure 5, the AMC peak was noted $6 \mathrm{hr}$ after ConA injection and it was significantly reduced by zVAD-fmk; thus, ConA treatment led to caspase activation. Furthermore, the noted drop in hepatocyte $\mathrm{O}_{2}$ consumption $6 \mathrm{hr}$ after ConA administration (see Figure 2) could be due to caspase-induced inhibition of the mitochondrial function. The more prominent decrease in hepatocyte respiration at $12 \mathrm{hr}$ after ConA, on the other hand, was associated with areas of necrosis and deranged mitochondria (see Figures 6 and 8). Of note here, the hepatocyte nuclei and mitochondria remained relatively preserved 3 and $6 \mathrm{hr}$ after ConA administration to the hosts (Figure 7). The pathologic changes in ConA-induced hepatitis are heterogeneous, likely accounting for the variability in the rate of $\mathrm{O}_{2}$ consumption observed here. Again, the precise mechanism for this patchy accumulation of inflammatory cells and focal necrosis is presently unknown.

IFN- $\gamma$ is a key inflammatory cytokine in ConA-induced hepatitis [3]. The probable source of IFN- $\gamma$ is NKT cells recruited into the liver, whose numbers were found to be significantly elevated in C57BL/6 mice compared with their knock-out counterparts $12 \mathrm{hr}$ after ConA injection (Figure 9) [15-17]. In the studies here, the lack of IFN- $\gamma$ in the $\mathrm{C} 57 \mathrm{BL} / 6 \mathrm{IFN}-\gamma^{-1-}$ mice partially repressed the disease (Figure 8), even when a higher dose of ConA (20 mg/kg) was employed. Interestingly, liver tissue respiration was also less impacted in these mice. The progressive increases in serum IFN- $\gamma$, ALT, AST, and intracellular caspases in the ConA-treated $\mathrm{C} 57 \mathrm{Bl} / 6$ mice emulated the progression of hepatocyte morphologic changes (confirmed by light and electron microscopy). Inexplicably, however, the ultrastructural changes at 3 and $6 \mathrm{hr}$ after injection with ConA 
were unremarkable, and deranged mitochondria were noted only at $12 \mathrm{hr}$ (Figure 8 ).

The observed enhancement of hepatocyte respiration in ConA hepatitis is not a direct action of IFN- $\gamma$ (Additional file 1: Figure S3). It is due to the ConA-induced disease, in which IFN- $\gamma$ contributes to its pathogenesis. For example, NKT cells $\left(\mathrm{CD}^{+} \mathrm{NKT}^{+}\right)$were significantly present in the wild-type mice compared to IFN $-\gamma^{-/-}$mice $(\mathrm{p}<0.005$, Figure 9).

\section{Conclusion}

In conclusion, the results of the current studies show increases in hepatocyte $\mathrm{O}_{2}$ consumption $3 \mathrm{hr}$ after ConA treatment. This finding appears to reflect higher metabolic energy expenditure early in the course of disease.

\section{Additional file}

Additional file 1: Figure S1. Typical runs of liver tissue respiration with cyanide and glucose oxidase are shown below. NaCN (10 mM) inhibited 82$86 \%$ of liver $\mathrm{O}_{2}$ consumption, confirming that the oxidation occurred in the mitochondrial respiratory chain. The remaining $\mathrm{O}_{2}$ in the solution was depleted with the addition of glucose oxidase $(50 \mu \mathrm{g} / \mathrm{ml})$. Figure S2. ConA did not significantly alter liver tissue respiration in vitro. A representative experiment is shown below. Briefly, murine liver specimens (4-13 mg) were incubated in vitro at $37^{\circ} \mathrm{C}$ with and without $10 \mu \mathrm{g} / \mathrm{ml} \mathrm{ConA}$ in $\mathrm{KH}$ buffer (continuously gassed with $95 \% \mathrm{O}_{2}: 5 \% \mathrm{CO}_{2}$ ) for up to $8 \mathrm{hr}$. Minute zero corresponds to time of sacrifice of the animal. Samples were alternatively removed from the incubation solution, rinsed with the same buffer, and placed in the instrument for $\mathrm{O}_{2}$ measurements at $37^{\circ} \mathrm{C}$. Rates of respiration, $k$ in $\mu \mathrm{M} \mathrm{O}_{2} \mathrm{~min}^{-1}$ and $k_{c}$ in $\mu \mathrm{M} \mathrm{O}_{2} \mathrm{~min}^{-1} \mathrm{mg}^{-1}$, are shown at the bottom of the runs. Similar results were observed with higher ConA concentrations (data not shown). Figure S3. IFN- $\gamma$ inhibited liver tissue respiration in vitro. Liver specimens ( $\sim 25 \mathrm{mg}$ each) were incubated in vitro at $37^{\circ} \mathrm{C}$ in $\mathrm{KH}$ buffer continuously gassed with $95 \% \mathrm{O}_{2}: 5 \% \mathrm{CO}_{2}$. Samples were sequentially removed from the incubation solution and placed in the oxygen vial for measurement of respiration. Minute zero corresponds to time of sacrifice of the animal. At indicated time points, IFN- $\gamma(100,50$ or $10 \mathrm{ng} / \mathrm{mL})$, sodium cyanide $(\mathrm{CN}, 10 \mathrm{mM})$ or glucose oxidase $(\mathrm{GO}, 5 \mu \mathrm{g} / \mathrm{mL})$ were added. Rates of respiration, $k$ in $\mu \mathrm{M} \mathrm{O}_{2} \mathrm{~min}^{-1}$, are shown. Figure S4. Micrographs of hematoxylin-stained paraffin embedded liver sections of uninjected (A) or PBS ( $\mathrm{C}$, at $12 \mathrm{hr}$ ) injected C57Bl/6 and uninjected (B) or PBS injected (D, at $12 \mathrm{hr}$ ) $\mathrm{C} 57 \mathrm{Bl} / 6 \mathrm{IFNy}{ }^{-1-}$ mice. Note the absence of infiltrations in any of the sections and the prominent sinusoids in PBS injected livers of both strains. $\operatorname{Bar}=50 \mu \mathrm{m}$.

\section{Competing interest}

The authors claim no conflicts of interest. The authors alone are responsible for the contents of this manuscript.

\section{Authors' contributions}

$M A, E M B$ and AKS designed the study, carried out the analysis, interpreted the data and drafted the manuscript. AS conceived of the study, measured respiration, ATP content and caspase activity. EMB examined histological and immunohistochemical staining. All authors read and approved the final manuscript.

\section{Acknowledgements}

This study was funded by the UAE University

\section{Author details}

'Department of Immunology, College of Medicine and Health Sciences, United Arab Emirates University, Al Ain, Abu Dhabi, United Arab Emirates (UAE). ${ }^{2}$ Department of Anatomy, College of Medicine and Health Sciences, United Arab Emirates University, Al Ain, Abu Dhabi, United Arab Emirates
(UAE). ${ }^{3}$ Department of Pediatrics, College of Medicine and Health Sciences, United Arab Emirates University, Al Ain, Abu Dhabi, United Arab Emirates (UAE).

Received: 2 July 2012 Accepted: 13 December 2012

Published: 12 January 2013

\section{References}

1. Tiegs G, Hentschel J, Wendel JA: T-Cell-dependent experimental liver injury in mice inducible by concanavalin A. J Clin Invest 1992, 90:196-203.

2. Tiegs $\mathrm{G}$ : Experimental hepatitis and the role of cytokines. Acta Gastroenterol Belg 1997, 60:176-179.

3. Takeda K, Hayakawa Y, Van Kaer L, Matsuda H, Yaqita H, Okumura K: Critical contribution of liver natural killer T-cells to a murine model of hepatitis. Proc Natl Acad Sci USA 2000, 97:5498-5503.

4. Leist M, Wendel A: A novel mechanism of murine hepatocyte death inducible by concanavalin A. Hepatology 1996, 25:948-959.

5. Margalit M, Abu Ghazala S, Alper R, Elinav E, Klein A, Doviner V, Sherman Y, Thalenfeld B, Engelhardt D, Rabbani E, llan Y: Glucocerbroside treatment ameliorates ConA hepatitis by inhibition of NK T lymphocytes. Am J Physiol 2005, 289:G917-G925.

6. Rahman TM, Hodgson HJ: Animal models of acute hepatic failure. Int $J$ Exp Path 2000, 81:145-157.

7. Tao Z, Penefsky HS, Goodisman J, Souid AK: Caspase activation by cytotoxic drugs (the caspase storm). Mol Pharm 2007, 4:583-585.

8. Al-Shamsi M, Al-Samri M, Al-Salam S, Conca W, Benedict S, Sudhadevi M, Biradar A, Asefa T, Souid A: Biocompatibility study of mesoporous silicate particles with cellular bioenergetics in murine tissues. Chem Res Toxicol 2010, 11:1796-1805.

9. Al Samri MT, Al Shamsi M, Al-Salam S, Marzouqi F, Al Mansouri A, Al-Hammadi S, Balhaj G, Al Dawaar SK, Al Hanjeri RS, Benedict S, Sudhadevi M Conca W, Penefsky HS, Souid AK: Measurement of oxygen consumption by murine tissues in vitro. J Pharmacol Toxicol Meth 2011, 63:196-204.

10. Shaban S, Marzouqi F, Al Mansouri A, Penefsky H, Souid AK: Oxygen measurements via phosphorescence. Computer Meth Programs Biomed 2010, 100:265-268.

11. Lo LW, Koch CJ, Wilson DF: Calibration of oxygen-dependent quenching of the phosphorescence of Pd-meso-tetra (4-carboxyphenyl) porphine: A phosphor with general application for measuring oxygen concentration in biological systems. Anal Biochem 1996, 236:153-160.

12. Knolle PA, Gerke G, Löser E, Dienes HP, Gantner F, Tiegs G, Meyer zum Büschenfelde K, Lohse AW: Role of sinusoidal endothelial cells of the liver in Concanavalin A-induced hepatic injury in mice. Hepatology 1996, 24:824-829.

13. Sass G, Heinlein S, Agli A, Bang R, Schumann J, Tiegs G: Cytokine expression in three mouse models of experimental hepatitis. Cytokine 2002, 19:115-120.

14. Gottlier E, Van der Heiden MG, Thompson CB: Bcl-xL prevents the initial decrease in mitochondrial membrane potential and subsequent reactive oxygen species production during TNF a-induced apoptosis. Mol Cell Biol 2000, 20:5680-5689.

15. Tagawa YI, Sekikawa K, Iwakura Y: Suppression of ConA-induced hepatitis in IFN- $\gamma^{-1-}$ mice, but not in $\mathrm{TNFa}^{-/-}$mice. J Immunol 1997, 159:1418-1428.

16. Siebler J, Wirtz S, Klein S, Protschka M, Blessing M, Galle PR, Neurath MF: A key pathogenic role for the STAT1/T-bet signaling pathway in T-cellmediated liver inflammation. Hepatology 2003, 38:1573-1580.

17. Jaruga B, Hong F, Kim WH, Gao B: IFN- $\gamma / S T A T 1$ acts as a pro-inflammatory signal in T-cell-mediated hepatitis via induction of multiple chemokines and adhesion molecules: A critical role of IRF-1. Am J Physiol 2004, 287:G1044-G1052.

doi:10.1186/1471-230X-13-6

Cite this article as: Al-Shamsi et al:: Derangements of liver tissue bioenergetics in Concanavalin A-induced hepatitis. BMC Gastroenterology 2013 13:6. 